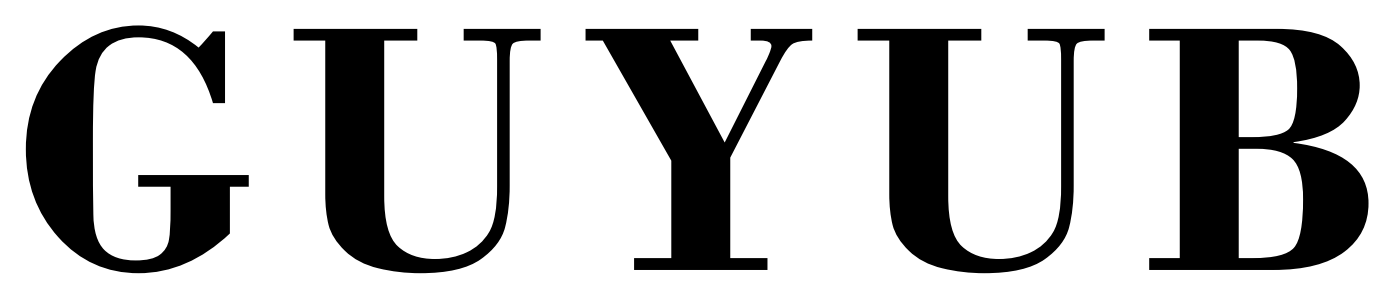

Journal of Community Engagement

Vol. 2, No. 2, Agustus 2021

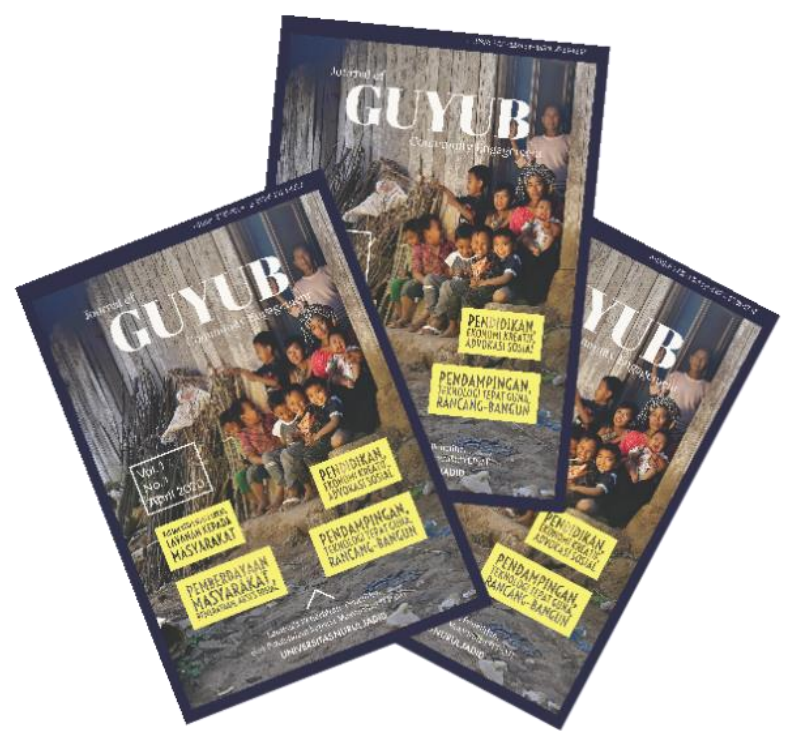

PKM Pendampingan Santri Nurul Jadid melalui Gerakan Literasi Cerdas dalam Membentuk Komunitas Pelajar Berkarakter Islam di Pondok Pesantren Nurul Jadid

Faizatul Widat, Afita Khoirun Nisa', Wardatul Habibah, Wahibatul Mas'ula, Nikmatul Hosniah, Jamilatul Masnunah, Hamidah

PKM Penyuluhan Pembuatan dan Penyemprotan Disinfektan (PEPEDES) sebagai Upaya Pencegahan Covid-19 di Desa Kalikajar Kulon Probolinggo

Fahrudin, Ayu Midyah Putri, Abdul Hamid Isnaini, Abdul Latif Isnaini, Duwi Handika Okta Rotama, Rosi Nurjannah, Suharno

PKM Pendampingan Penyusunan Kurikulum Sekolah Ramah Anak pada Taman Kanak Kanak (TK) Az-Zainiyah II Paiton Probolinggo

Abu Hasan Agus R, Durratul Mashunah, Hostin, Hilyah Mashunah, Siti Rahayu, Atik Hikmatuz Zakiyah 


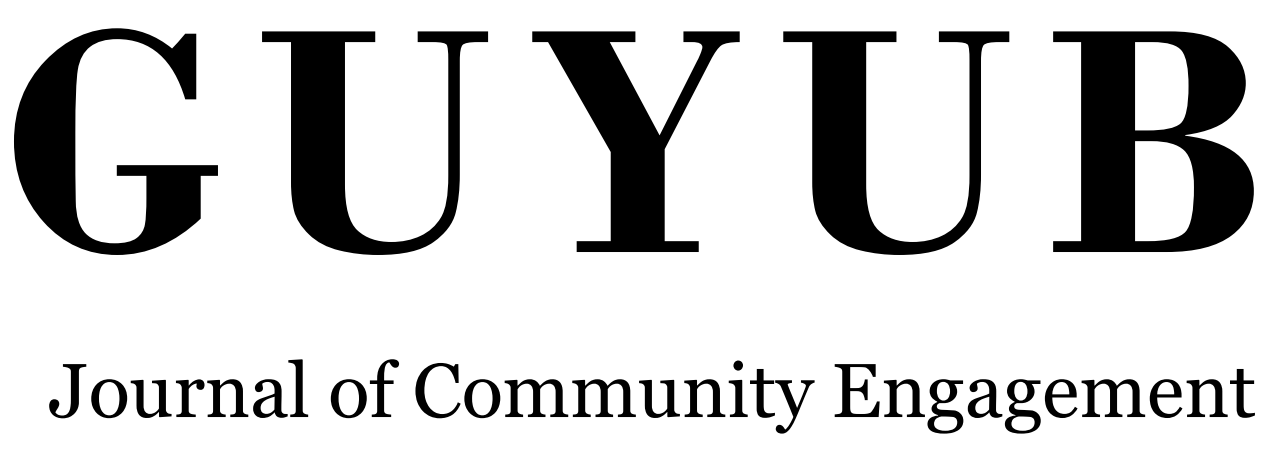




\section{G U Y U B}

\section{Journal of Community Engagement}

Vol. 2, No. 2, 2021

\section{Editor in Chief}

Achmad Fawaid, (SCOPUS ID: 57214837323)

\section{Managing Editors}

Hasan Baharun, (ID SCOPUS : 57200983602)

Sugiono Sugiono, (SCOPUS ID : 57199578160)

Ismail Marzuki, (SCOPUS ID: 57201500245

Subhan Rachman, (SCOPUS ID: 57192937912)

Nurul Huda, (SINTA ID: 6119615)

Syamsuri, (SINTA ID: 6116825)

Ridhatullah Assya'bani, (SINTA ID: 6200862)

\section{Peer Reviewers}

Miftahul Huda, (SINTA ID: 6171566), University of Antwerp, Belgium Achmad Naufal Irsyadi (SINTA ID: 6704870), Universitas Nurul Jadid, Indonesia Sukamto Sukamto, (SINTA ID: 5979034), Universitas Widya Gama Malang, Indonesia Deny Utomo, (SINTA ID: 6016108), Universitas Yudharta Pasuruan, Indonesia Fariz Alnizar, (SCOPUS ID: 6659824), UNUSIA Jakarta, Indonesia Fuad Rahman, (SCOPUS ID: 57201474778), UIN Sulthan Thaha Saifuddin Jambi, Indonesia Saifuddin Zuhri Qudsy, (SCOPUS ID: 57213595165), UIN Sunan Kalijaga Yogyakarta, Indonesia Akhmad Anwar Dani, (SINTA ID: 14305), IAIN Surakarta, Indonesia Maufur Maufur, (SINTA ID: 5989329), IAIN Kediri, Indonesia Siti Mahmudah Noorhayati, (SINTA ID: 6726997), IAIN La Roiba Bogor, Indonesia Busro Busro, (SCOPUS ID: 57205022652), UIN Sunan Gunung Djati Bandung, Indonesia Akmal Mundiri, (SCOPUS ID: 57205059378), UNUJA Probolinggo, Indonesia

\section{Section Editor}

Ahmad Zubaidi, Universitas Nurul Jadid, Probolinggo, Indonesia 
GUYUB: Journal of Community Engagement is a multidisciplinary journal which aims to disseminate the conceptual thoughts and research results in the area of community service. This journal focuses on the main problems of the community engagement areas, such as (1) training, marketing, appropriate technology, design; (2) student community services; (3) community empowerment, social access; (4) education for sustainable development, etc.

GUYUB: Journal of Community Engagement is published three times a year (April, August, December) by Lembaga Penerbitan, Penelitian, dan Pengabdian kepada Masyarakat (LP3M) Universitas Nurul Jadid, Paiton, Probolinggo, Jawa Timur, Indonesia.

Editorial Office:

GUYUB: Journal of Community Engagement

Lembaga Penerbitan, Penelitian, dan Pengabdian kepada Masyarakat (LP3M) Universitas Nurul Jadid, Paiton, Probolinggo, Jawa Timur, Indonesia 67291.

Phone: 088830 77077, Hp: 082318007953

Email: jurnal.guyub@gmail.com

Website: https://ejournal.unuja.ac.id/index.php/guyub/index 


\section{Tables of Content}

178-191

PKM Pendampingan Santri Nurul Jadid melalui Gerakan Literasi Cerdas dalam Membentuk Komunitas Pelajar Berkarakter Islam di Pondok Pesantren Nurul Jadid

Faizatul Widat, Afita Khoirun Nisa', Wardatul Habibah, Wahibatul Mas'ula, Nikmatul Hosniah, Jamilatul Masnunah, Hamidah

192-201

PKM Pelatihan Deep-Listening untuk Meningkatkan Kemampuan Berbahasa Inggris Santri Nurul Jadid Durratul Hikmah, Taufiqur Rahman, Irfan Wahyudi, Nur Hayati, Ahmad Zainullah, Kuni Zakiya Maskuroh

$202-210$

PKM Pendampingan Speaking Skill dengan Metode TROPIG di Wilayah Al Hasyimiyah Pondok Pesantren Nurul Jadid

Syaiful Islam, Nur Azizah, Rifdatul Qomariyah, Anis Fitria, Nurul Hamidah, Masrufah Masrufah

\section{1-224}

PKM Penyuluhan Pembuatan dan Penyemprotan Disinfektan (PEPEDES) sebagai Upaya Pencegahan Covid-19 di Desa Kalikajar Kulon Probolinggo

Fahrudin, Ayu Midyah Putri, Abdul Hamid Isnaini, Abdul Latif Isnaini, Duwi Handika Okta Rotama, Rosi Nurjannah, Suharno

225-232

PKM Pelatihan Pengisian Pengajuan Izin Operasional Taman Pendidikan Al-Quran secara Online Moh Jasri, Muhammad Romdloni, Mohammad Akmalor Riski, Nurul Hidayatullah, Muhammad Hasan Andika, Yogi Angga Praditya, Syukron Khafi, Shancen Ammabiel

\section{3-249}

PKM Pelatihan Pemanfaatan E-Learning Berbasis Teknologi Berbasis Platform Google Classroom bagi Guru Madrasah Ibtidaiyah Nurul Mun'im (MINM) Paiton Probolinggo

Feriska Listrianti, Nur Ika Sari, Siti Khomariya, Huswatun Hasanah, Millatun Hanifah, Deviyatul Hasanah

250-264

PKM Pelatihan Tutor Lembaga Kebahasaan Az-Zainiyah melalui Game Islami untuk Meningkatkan Keterampilan Berbicara Bahasa Inggris

Bradhiansyah Tri Suryanto, Nur Hasanah, Nuril Diar Anas, Sri Waliyul Hasanah, Syaiful Syaiful, Lia Umami

\section{5-275}

PKM Deteksi Dini Kelainan Tumbuh Kembang dengan Skrining Denver II dan Health Education di Taman Pendidikan Anak Shaleh Nurul Jadid Paiton Probolinggo

Zainal Munir, Zainul Hasan, Siti Nur Kholishoh, Melinia Akhirul Fitri 
PKM Habituasi Nilai-Nilai Keagamaan melalui Kegiatan Rohani DITABERHAMAN dalam Menciptakan Kesalehan Sosial di Pondok Mahasiswi (POMASI) Nurul Jadid Paiton Probolinggo

Zakiyah BZ, Ana Muthmainnah, Aminatuz Zuhriyah, Hamidah Hamidah, Miftahul Jannah, Wardatus Sholihah, Elok Nafiqoh

293-302

PKM Diversifikasi Ragam Produk Olahan Berbahan Dasar Ikan Teri sebagai Upaya Peningkatan Ekonomi Masyarakat Paiton Probolinggo

Saifuddin, Andre Dimas Fernando Putra, Moch Sofyan, Fadhlur Rohman, Mohammad Hasan Ainul Yaqin, Nailis Saadah Ali

303-312

PKM Pendampingan Penyusunan Kurikulum Sekolah Ramah Anak pada Taman Kanak Kanak (TK) AzZainiyah II Paiton Probolinggo

Abu Hasan Agus R, Durratul Mashunah, Hostin Hostin, Hilyah Mashunah, Siti Rahayu, Atik Hikmatuz Zakiyah

\section{3-325}

PKM Pelaksanaan Kegiatan Ekstrakurikuler Keagamaan dalam Membangun dan Mengembangkan Bakat dan Minat Santri pada Bidang Keagamaan di Madrasah Tsanawiyah (MTs) Nurul Jadid Probolinggo

Abdullah, Habibaturrohmah Habibaturrohmah, Halimatus Sakdiyah, Aisyah Amini, Putri Yunita Sari, Lilis Sulistiawati, Fitriyatun

326-341

PKM Sosialisasi Aplikasi Edmodo sebagai Alternatif Media Pembelajaran Daring di Madrasah Ibtidaiyah (MI) Az-Zainiyah II Paiton Probolinggo

Niken Septantiningtyas, Suhairiyah Suhairiyah, Fadilatul Hasanah, Umatuz Sholihah

$342-350$

PKM Pendampingan Pelatihan Penulisan Karya Tulis IImiah dalam Meningkatkan Kompetensi Guru di Madrasah Tsanawiyah (MTs) Nurul Jadid Paiton Probolinggo

Musolli Ready, Moh. Amir Kholili, Moh. Abd Mu'iz, Jefri Jefri, Moh. Agus, Moh. Ridwan Kamil

$351-360$

PKM Literasi Penguatan 3-M (Memakai Masker, Mencuci Tangan, dan Menjaga Jarak) Melalui Metode Storytelling di Pondok Pesantren Nurul Jadid Probolinggo

Mohammad Sofyan Adi, Dina Nur Faizah, Kamelia Yulia Novita, Robiatul Adawiyah, Ulfatul Nimatillah, Nuriah Waizul Romdani

361-368

PKM Pendampingan Pembelajaran Materi Bangun Datar dengan Billingual LED Running Text di Madrasah Ibtidaiyah (MI) Az-Zainiyah II Paiton Probolinggo

Nur Hamid, Muhammad Faiz Nailun Ni'am, Cahyu Guswita, Saiful Islam, Silviana Qomariyah, Siti Fatimah, Siti Khoifah

369-383

PKM Pendampingan Literasi Business Plan untuk Meningkatkan Pengetahuan dan Keterampilan Berwirausaha Santri Pesantren Nurul Jadid Mohammad Syaiful Suib, Yoviana Fitri, Lailatus Sa'adah, Nuril Fitriani, Widad Ulfatul Mawaddah Hadi, Siti Aisyah, Isna Shifah 
384-403

PKM Penanaman Karakter Berbasis Keagamaan bagi Warga Binaan Rumah Tahanan Kelas II. B Kraksaan Probolinggo Jawa Timur

Ahmad Fawaid, Muhammad Zaimul Millah, Achmad Naufal Baidawi, Siti Arofah, Nur Khofifah, Elmiyatus Soliha, Syukron Jazila, Rif'ah Hasanah, M Zainuddin

404-416

PKM Pendampingan Menghafal Al-Quran dengan Metode An-Nur pada Siswa Kelas X IPA Tahfidz Madrasah Aliyah Nurul Jadid Paiton Probolinggo

Abdurrahman, Indriani Putri Ayu Lestari, Lailia Mutmainnah, Hakimatus Sailah, Ika Fitri Anwar, Sofiya Mauliza, Nadya Afkarina

417-423

PKM Peningkatan Pendapatan pada Bidang Keputrian Wilayah Az-Zainiyah Pondok Pesantren Nurul Jadid melalui Strategi Pemasaran Berbasis Web

Anis Yusrotun Nadhiroh, Dina Wahyuni Suciati, Dzurrotun Nafila, Eva Nurmaliya, Nabila Maulidir Roziqina Fara 


\title{
PKM Peningkatan Pendapatan pada Bidang Keputrian Wilayah Az-Zainiyah Pondok Pesantren Nurul Jadid melalui Strategi Pemasaran Berbasis Web
}

\author{
Anis Yusrotun Nadhiroh ${ }^{1}$, Dina Wahyuni $S^{2}$, Dzurrotun Nafila ${ }^{3}$, Eva \\ Nurmaliya ${ }^{4}$, Nabila Maulidir $\mathrm{R}^{5}$ \\ Universitas Nurul Jadid $1,2,3,4,5$ \\ \{ayusrotun@gmail.com ${ }^{1}$, dinadnanart@gmail.com², dzurrotunnafila@gmail.com³ \\ evamaliyah2057@gmail.com ${ }^{4}$,roziqina32@gmail.com $\left.{ }^{5}\right\}$
}

Submission: 2021-08-10 Received: 2021-08-31 Published: 2021-08-31

Keywords:
Islamic Boarding
School,
Marketing,
Website

Pesantren Nurul Jadid,

Pemasaran, Website

\begin{abstract}
The internet is one of the technologies that is inevitable in today's digital era. One of the effects of the internet also has an impact on the business world, among others, by the growing development of e-commerce and the decreasing number of offline retailers. Therefore, the use of the internet/e-commerce as an alternative to sales must be carried out by the Women's Division in selling products made by the skills of the students of the Nurul Jadid Islamic Boarding School. This service aims to be able to help the female part of the Nurul Jadid Islamic Boarding School to introduce products through sales via the internet and its derivatives. In addition, this service also aims to introduce products made by students with better marketing strategies, including the use of more eye-catching packaging and selling so that they can be easily accepted by the millennial generation. This service method includes training on how to use website-based marketing applications and workshops on making products that will be sold. The results of this service are websitebased applications through applications that are made to receive orders from customers, can process sales data more effectively and efficiently.
\end{abstract}

Internet merupakan salah satu teknologi yang tidak mungkin terelakan lagi di era digital saat ini. Salah satu efek dari adanya internet juga berdampak pada dunia bisnis antara lain dengan semakin berkembangnya ecommerce dan semakin menurunnya jumlah jumlah retail offline. oleh karena itu penggunaan internet/ e-commerce sebagai alternatif penjualan harus dilakukan oleh semua pengusaha termasuk Bidang Keputrian dalam menjual produk hasil keterampilan santri Pondok pesantren Nurul Jadid. Pengabdian ini bertujuan untuk dapat membantu Pondok Pesanten Nurul Jadid bagian keputrian untuk mengenalkan produk melalui penjualan lewat internet dan turunannya. selain itu pengabdian ini juga bertujuan untuk mengenalkan produk hasil karya santri dengan strategi pemasaran yang lebih baik antara lain dengan penggunaan kemasan yang lebih eye catching dan menjual sehingga dapat mudah diterima oleh generasi milenial. Metode Pengabdian ini antara lain pelatihan cara pengunaan aplikasi pemasaran berbasis wesbsite dan workshop pembuatan produk yg akan dijual. Hasil dari pengabdian ini yaitu aplikasi berbasis website melalui aplikasi yang dibuat dapat menerima pesanan dari pelanggan, dapat melakukan pengolahan data penjualan secara lebih efektif dan efisien. 


\section{Pendahuluan}

Keberadaan website menimbulkan pemikiran baru bagi pelaku bisnis yaitu untuk mengatasi rintangan waktu dan ruang yang selama ini menjadi masalah pada sistem penjualan secara konvensional. website merupakan sistem baru bagi pelaku bisnis untuk memanfaatkan teknologi agar lebih efektif dan efisien dalam bertransaksi secara online dengan website sebagai medianya. Melalui website sebuah perusahaan dapat memiliki sebuah pasar internasional. Bisnis dapat dijalankan tanpa harus terkendala pada batas negara dengan adanya teknologi digital. Pihak perusahaan dapat bertemu dengan partner dan kliennya dari seluruh penjuru dunia. Hal ini menciptakan sebuah lembaga multinasional virtual. Konsumen dapat berbelanja atau mengolah transaksi lain dalam 24 jam sepanjang hari, sepanjang tahun di sebagian besar lokasi. Dengan website proses pengantaran produk menjadi lebih mudah. Farhan, R., \& Purwandari, N. (2018)

Tjiptono, (2012), bahwa strategi pemasaran adalah rencana yang menjabarkan rencana ekspektasi perusahaan akan dampak dari berbagai aktivitas atau program pemasaran terhadap permintaan produk atau lini produknya di pasar sasaran tertentu. Perusahaan bisa menggunakan dua atau lebih program pemasaran secara bersamaan, sebab setiap jenis program (seperti periklanan, promosi penjualan, personal selling, layanan pelanggan, atau pengembangan produk) memilki pengaruh yang berbedabeda terhadap permintaan. Oleh sebab itu, dibutuhkan mekanisme yang dapat mengkoorfinasikan program-program penmasaran agar program itu sejalan dan terintegrasi secara sinergistik. Mekanisme ini disebut strategi pemasaran.

Penelitian yang dilakukan oleh Sutri Handayani (2018) pada studi kasus Toko Kun sering mengalami permasalahan diantaranya media promosi yang hanya menggunakan spanduk, penjualan masih sebatas offline, penyimpanan data dan pencetakan laporan masih berupa pencatatan dalam bentuk arsip. Hasil dalam penelitian ini adalah website, yang penjualan berbasis e-commerce dapat dijadikan sebagai media promosi, mempermudah proses penjualan yang dilakukan secara online, serta dapat mempermudah dalam pengolahan data dan pencetakan laporan yang tidak lagi memerlukan pencatatan dalam bentuk arsip. 
Penelitian selanjutnya yang dilakukan oleh Sidik, dkk (2019) pada studi kasus Toko Busana Depok masih menggunakan cara manual yaitu dengan mencatat setiap data produk dan setiap transaksi produk yang terjadi sangat tidak efektif. Hasil dari penelitian ini Sistem Informasi Penjualan Berbasis Web E-Commerce dapat memudahkan user dalam proses transaksi pembelian produk di toko NB Busana dan memudahkan pihak toko dalam proses transaksi.

Dari kutipan diatas dapat disimpulkan bahwa toko online atau biasa yang di sebut dengan ecommerce merupakan bagian yang sangat penting dalam pemasaran produk dalam sebuah perusahaan. Perusahaan yang memasarkan produk mereka hanya terbatas kedalam toko-toko saja tanpa adanya toko online, membuat produk perusahaan tersebut kurang dikenal oleh masyarakat dan keuntungan perusahan tersebut menjadi berkurang.

Bidang Keputrian wilayah Az-Zainiyah Pondok Pesantren Nurul Jadid merupakan usaha keterampilan yang memproduksi dan menjual produk hasil karya mahasatri secara offline, keputrian Az-Zainiyah ini juga menerima produk design yang mana konsumen dapat memesan beberapa produk kerajinan tangan salah satunya tas rajut, dompet rajut dan pot daur ulang dari handuk atau kain bekas sesuai keinginannya. Dalam pengembangan bisnisnya, bidang keputrian Az-zainiyah terus berusaha untuk memperluas target pasarnya sampai luar kota bahkan seluruh Indonesia. Untuk mencapai tujuannya, memerlukan website yang dapat menghubungkan penjual dan pembeli yang berbeda tempat dan tidak akan menjadi kendala dalam melakukan transaksi. Calon pembeli dapat mengetahui informasi mengenai Produk yang dijual pada keputrian Az-zainiyah Pondok Pesantren Nurul Jadid.

Dari permasalahn yang dihadapi oleh bidang keputrian dapat disimpulkan bahwa bidang usaha tersebut membutuhkan sebuah aplikasi toko online yang bisa menampung produk-produk yang ada dalam aplikasi tersebut, sehingga dalam memasarkan produknya, serta memberikan kemudahan kepada konsumen dalam mendapatkan informasi maupun dalam membeli produk yang dijual oleh bidang usaha tersebut dan membantu dalam mempromosikan produk kepada konsumen, sehingga keuntungan yang di peroleh dapat tercapai dengan maksimal, bagi admin diberi kemudahan dalam pengolahan data transaksi untuk pembuatan laporan penjualan. 


\section{Metode}

Berdasarkan permasalahan yang ada tentunya harus ada solusi untuk pemecahan masalah tersebut. Suatu metode dan rancangan khusus harus direalisasikan untuk menjawab permasalahan mitra yang sedang terjadi. Metode pendekatan yang akan dilakukan pada program pengabdian masyarakat yang ditawarkan untuk menyelesaikan persoalan yang terkait adalah: (1) Pelatihan produksi, (2) Pelatihan Pemasaran, (3) Pelatihan Manajemen Usaha,(4) Pendampingan, diuraikan sebagai berikut:

\section{Metoda Pelatihan Produksi}

Metoda pelatihan produksi, pengusul bersama mitra dalam hal ini Bidang Keputrian Pondok Pesantren Nurul Jadid Desa karanganyar merencankan memberikan keterampilan produksi dari handuk bekas menjadi pot, kayu stik menjadi miniature bangunan dan konektor masker.

\section{Metoda Pelatihan Pemasaran}

Metoda pelatihan pemasaran, pengusul bersama mitra dalam hal ini bidang keputrian Pondok pesantren Nurul Jadid desa Karanganyar merencanakan memberikan penyuluhan dalam mengelola produksi yang berorientasi pada pesanan bukan pada persediaan, hal ini menyebabkan lemahnya fungsi pemasaran, kelompok usaha tidak memiliki strategi pemasaran, hal ini bisa diakibatkan belum mantapnya perencanaan bisnis.

\section{Metoda Pendampingan}

Metoda pelatihan pemasaran, pengusul bersama mitra dalam hal ini bidang keputrian Pondok Pesantren Nurul Jadid desa Karanganyar merencanakan memberikan pendampingan untuk mendapatkan bahan yang berkulitas bagus dengan cara memberikan contoh-contoh serta penerapan pemakaian maupun penggunaan demi kelancaran produksi.

\section{Hasil}

Kegiatan ini juga dibantu oleh beberapa mahasiswa program studi teknik Sistem Informasi dan teknik Informatika Universitas Nurul Jadid. Tahapan pertama sebelum melakukan kegiatan pelatihan baik sesi kelas maupun sesi lapangan adalah tahapan persiapan. Mitra diberi pengetahuan mengenai komponen dasar dalam perancangan dan pembuatan kemasan produk dan 
hal yang membedakan sistem pemasaran dan penjualan secara offline dan online. Praktik (pelatihan sesi lapangan) merupakan tahapan kegiatan yang tidak terpisahkan dari serangkaian kegiatan pengabdian kepada masyarakat bagian keputrian Az-zainiyah Pondok Pesantren Nurul Jadid. Salah satu kegiatan pada tahapan ini adalah khalayak sasaran diberitahu dan dilatih menggunakan beberapa peralatan yang berhubungan dengan pengemasan produk seperti pemotongan kertas stiker, kemasan kraft plastik, dan kemudian kemasan.

\section{Hasil Produk}

Beberapa produk yang dibuat oleh Mahasatri diantaranya ; pot bunga dari bahan daur ulang handuk bekas, Pot Bunga dari bahan jangel jagung, pada gambar 1.
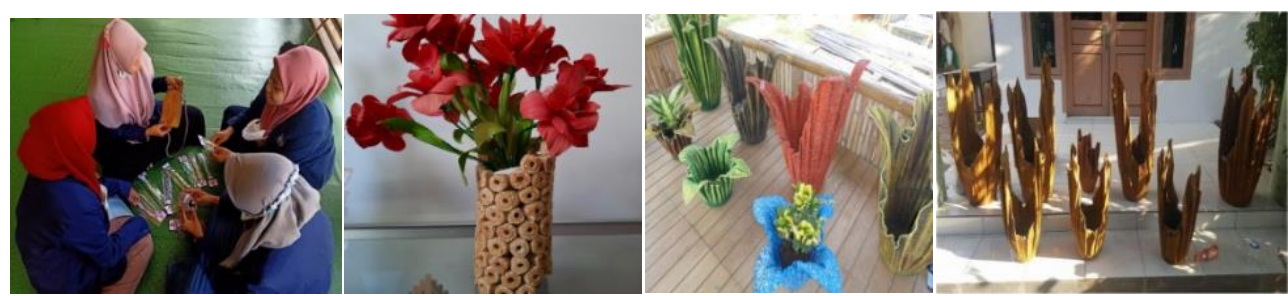

Gambar 1. Produk Keterampilan mahasantri

\section{Pembahasan}

\section{Implementasi Aplikasi (Halaman Utama)}

Halaman utama dari aplikasi yang dibangun menampilkan Gambar produk unggulan, kategori dari produk dan daftar dari barang atau produk yang dihasilkan di Az-zainiyah Store. Tampilan dari halaman utama dapat dilihat pada Gambar 2. 


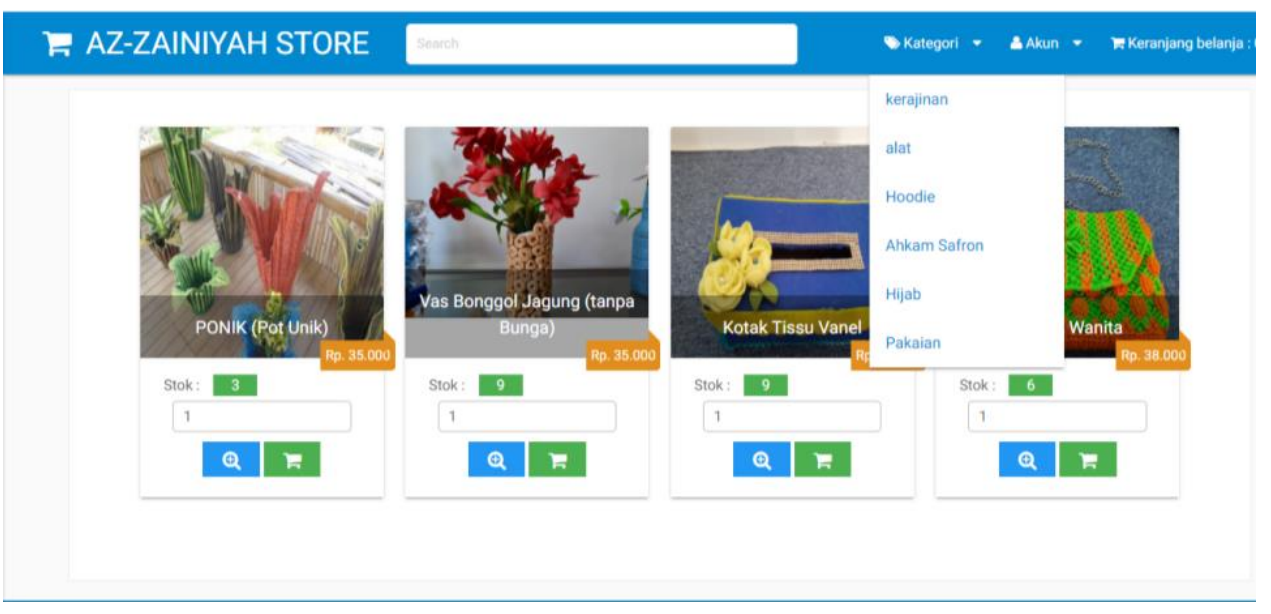

Gambar 2. Halaman Utama Az-Zainiyah Store

Penerapan pemasaran online dinilai cukup efektif bagi Bidang ketrampilan Az-zainiyah Pondok Pesantren Nurul Jadid. Dimana hal tersebut dapat dilihat dari perubahan sebelum dan setelah menerapkan pemasaran online dalam penjualan produk khususnya dalam jumlah pendapatan. Perbaikan dalam hal pengemasan, pemasaran dan penjualan online terus dilakukan oleh mitra dan didampingi oleh tim pengabdian kepada masyarakat LPPM Universitas Nurul Jadid.

\section{Kesimpulan}

E-Commerce untuk Optimalisasi Pemasaran Produk di Era Digital Bagi Keputrian Az-Zainiyah Pondok Pesantren Nurul Jadid telah selesai dilakukan. Beberapa indikator capaian program pengabdian telah diperoleh, mulai dari pembuatan dan penggunaan kemasan produk, pembuatan website. Proses pemasaran produk berjalan cukup baik yang ditunjukkan dengan adanya penambahan pemesanan produk mahasatri, sehingga meningkatkan pendapatan bagi bidang usaha wilayah Az-zainiyah Pondok Pesantren Nurul jadid. Pemasaran terus dilakukan dengan memanfatkan halaman website "Az-zainiyah Store". 


\section{Pengakuan}

Kami ucapkan terima kasih kepada Lembaga Penerbitan, Penelitian dan Pengabdian Masyarakat Universitas Nurul Jadid yang memberikan dukungan materil sehingga kegiatan pengabdian masyarakat ini berjalan dengan lancar.

\section{Referensi}

A., S. H., \& Siregar. V. M. M. (2018). Jurnal Teknik Informasi dan Komputer(Teknikom). Perancangan Sistem Informaasi Berbasis Ecomerce Untuk Peningkatan Penjualan Produk Jersey Olah Raga, 1(2). 49-54.

Arif, M. F. (2019). Analisis dan Perancangan Sistem Informasi. Penerbit Qiara Media.

Eko, N. F. (2016). Jurnal Simetris. Perancangan Sistem Informasi Penjualan Online.

Farhan, R., \& Purwandari, N. (2018). Jurnal Sains dan Teknologi. Sistem Informasi Penjualan Berbasis Web.

Hidayati, S. (2018). ILKOM Jurnal Imiah. Perancangan Sistem Informasi Penjualan Berbasis E-comerce Studi Kasus Toko KUn Jakarta, 10(2), 182-189.

Hidayatullah, Priyanto, \& Kawist, J. K. (2017). Pemrograman WEB. Bandung: Informatika Bandung.

Lie, R. (2017). Sistem informasi penjualan pakaian berbasis web pada toko sweet batam.

Sidik, S., \& W. Putri, S. (2019). Implementasi Model Waterfall pada Sistem Informasi Penjualan Berbasis Web, 11.

Siregar, V. M. (2018). Jurnal Teknologi Informasi. Sistem Informasi Pembelian Dan Penjualan Pakaian pada Galoenk Dostro Pematagsiantar, 1(2), 182-227. 


\section{GUYUB}

\section{Journal of Community Engagement}

P-ISSN: 2723-1232

E-ISSN: 2723-1224

GUYUB: Journal of Community Engagement is is a multidisciplinary journal which aims to disseminate the conceptual thoughts and research results in the area of community service. This journal focuses on the main problems of the community engagement areas, such as (1) training, marketing, appropriate technology, design; (2) student community services; (3) community empowerment, social access; (4) education for sustainable development, etc.

GUYUB: Journal of Community Engagement is published three times a year (April, August, December) by Lembaga Penerbitan, Penelitian, dan Pengabdian kepada Masyarakat (LP3M) Universitas Nurul Jadid, Paiton, Probolinggo, Jawa Timur, Indonesia.

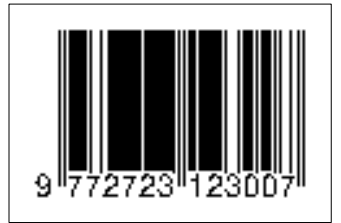

Editorial Office:

GUYUB: Journal of Community Engagement

Lembaga Penerbitan, Penelitian, dan Pengabdian kepada Masyarakat

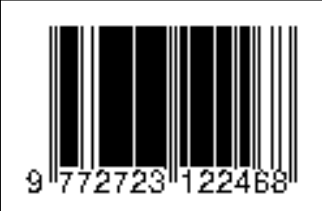

(LP3M) Universitas Nurul Jadid, Probolinggo, Jawa Timur, Indonesia 67291.

Phone: 088830 77077, Hp: 082318007953

Email: jurnal.guyub@gmail.com

Website: https://ejournal.unuja.ac.id/index.php/guyub/index 